\title{
Pheromones of the Scarabaeinae, II*. Composition of the Pheromone Disseminating Carrier Material Secreted by Male Dung Beetles of the Genus Kheper
}

B. V. Burger and Zenda Munro

Department of Chemistry, University of Stellenbosch, Stellenbosch 7600, South Africa

W. F. Brandt

Research Centre for Molecular Biology, Department of Biochemistry, University of Cape Town, Rondebosch 7700 , South Africa

Z. Naturforsch. 45c, 863-872 (1990); received January 5, 1990

Insect Pheromone, Pheromone Disseminating Protein, Dung Beetle, Scarabaeinae, Plasma Desorption Mass Spectrometry

Gel electrophoresis of the white flocculent pheromone disseminating secretions produced by males of the three dung beetle species, Kheper lamarcki, K. nigroaeneus and $K$. subaeneus, revealed that three different proteins with molecular masses of $c a .15 \mathrm{kDa}$ are the major constituents of these secretions. The molecular mass of these components in the secretions of $K$. lamarcki and $K$. nigroaeneus was determined more accurately by ${ }^{252} \mathrm{Cf}$ plasma desorption mass spectrometry to be $15451 \pm 10$ and $15477 \pm 10 \mathrm{Da}$ respectively. The $\mathrm{N}$-terminal amino acids in the major proteinaceous component of the secretions revealed similarities as well as differences in the primary structures of the proteins secreted by the three species. The amino acid composition of the secretions of the three species is closely related. Due to the presence of large amounts of aspartic and glutamic acid, and small amounts of the basic amino acids, the proteinaceous component of the carrier material is expected to have a low isoelectric point which, together with the presence of large amounts of the hydrophobic amino acids, may impart properties that are to be expected for a carrier material which is used for the dissemination of inter alia long-chain fatty acids and their esters.

Exposure of bovine pancreas trypsin, bovine albumin and the carrier protein of $K$. lamarcki to the vapour of 2,6-dimethyl-5-heptenoic acid, the major volatile constituent with electroantennogram activity in the secretion of this species, followed by quantitative determination of the acid adsorbed on these proteins, showed that albumin and the carrier protein have an approximately equal affinity for the acid, whereas trypsin retained only about one third of the amount of the acid adsorbed on the other two proteins. It was concluded that albumin should be a suitable substitute for the carrier protein in field tests with synthetic constituents of the abdominal secretion of these insects.

\section{Introduction}

The peculiar courtship behaviour of male Kheper lamarcki dung beetles, during which a white flocculent substance emerges from the sides of the first abdominal sternite and is brushed into the air by brushes on the tibiae of the hind legs, was described in a previous paper on the pheromones of the Scarabaeinae [1]. This visible secretion, which serves as a support for a number of relatively vola-

\footnotetext{
* For the preceding paper in this series see B. V. Burger, Z. Munro, M. Röth, H. S. C. Spies, V. Truter, G. D Tribe, and R. M. Crewe, Z. Naturforsch. 38c, 848 (1983).

Reprint requests to Prof. B. V. Burger.

Verlag der Zeitschrift für Naturforschung, D-7400 Tübingen $0341-0382 / 90 / 0700-0863 \$ 01.30 / 0$
}

tile compounds, was found to be a protein containing most of the proteogenic amino acids. The secretion appeared to be almost insoluble in various solvents and since this was expected to preclude the application of conventional purification techniques, no further analytical work was attempted initially. Although the carrier material presumably plays a role in modulating the dissemination of the semiochemicals from the abdominal secretion, only a few, relatively simple compounds were initially identified in the secretion of $K$. lamarcki, and it was therefore assumed that any inert carrier material should be suitable as support for synthetic compounds in field tests. The physical appearance of the carrier material as it is brushed into the air, resembles that of French chalk, which was therefore used in initial field tests, with only limited success, however. 
Advances in capillary column technology has led to the introduction of OH-terminated polysiloxane phases for the preparation of thermally stable capillary gas chromatographic columns, having high separating efficiencies [2]. Using such a glass capillary column, coated with OV-1701$\mathrm{OH}$, it was found that the abdominal secretion produced by calling Kheper lamarcki males is, in fact, an extremely complex mixture containing at least 60 constituents such as, inter alia, straightand branched-chain fatty acids, methyl and ethyl esters, as well as a series of hydrocarbons. A comparison of this secretion with that of $K$. subaeneus and $K$. nigroaeneus revealed that their secretions are equally complex and that similar compounds are produced by the three species, although only a few of these compounds are common to all three species. The identification of the volatile constituents present in the secretions of these dung beetle species will be communicated elsewhere.

Where related species occupy the same habitat, the integrity of their chemical signals may be of vital importance to their survival, especially when, as in the case of these Kheper beetles, a pair of dung beetles normally produces only one or two offspring per year. Using a solid carrier material impregnated with the semiochemicals has the advantage that such a "packaged" message will retain its integrity over long distances. Since the volatile fraction of the secretion contains compounds with widely different polarities, the polypeptide carrier will, without doubt, have a marked influence on the ratio in which these compounds are released into the atmosphere. Although synthesizing a protein as support material for field tests of the synthetic semiochemicals identified in the secretion was not envisaged, it was nevertheless clear that more specific information was required for the selection of a chemically similar and readily available protein for this purpose. In this paper the results of experiments towards the characterization of the abdominal carrier material of three Kheper species are discussed.

\section{Materials and Methods}

\section{Collection and purification of the carrier material}

The $n$-pentane, dichloromethane and chloroform used for extraction purposes were of residue analysis grade (Merck). All Pyrex glassware used in the handling of the material was heated to $500^{\circ} \mathrm{C}$ in an annealing oven to remove any traces of organic material. Spatulas, syringes, etc., which were used in handling the secretion, were cleaned by rinsing with the dichloromethane specified above.

Adult Kheper lamarcki and K. nigroaeneus dung beetles were trapped in Mkuzi Game Reserve in Natal, South Africa, during the early summer months by baiting pitfall traps [3] with fresh horse dung. K. subaeneus is not found in Mkuzi Game Reserve and beetles of this species were collected from rhinoceros dung middens in the neighbouring Hluhluwe Game Reserve. On arrival in Stellenbosch, one hind leg was removed from all the male beetles. Although a small percentage of the beetles died within a week or two after removal of a leg, this was the only possibility to prevent the dispersal of the secretion which, if it is not brushed off, collects at the side of the abdomen as a tuft of cottonwool-like material. The male and female beetles were kept at subtropical temperatures in greenhouses, the floors of which were covered with about $15 \mathrm{~cm}$ of moist sandy soil.

When disturbed, male dung beetles immediately stop secreting the attractant to investigate, and may even disappear underground together with a female. Males observed to assume the attractant secreting posture, were therefore fenced off from other beetles with aluminium strips. In many cases the production of secretion continued for periods up to $2 \mathrm{~h}$. The secreted material was removed periodically from the incapacitated side of the beetle with ophthalmic forceps to prevent contamination with dust particles and the evaporation of the pheromone from the carrier material. In the meantime the vial with material already collected, was kept cool in an ice-box. Tiny dust and dung particles picked up from the abdomen of the insects by the emerging secretion, were carefully removed from the secretion under a microscope. In a typical sample preparation, $3 \mathrm{mg}$ of the secretion collected from $K$. lamarcki was sonicated for 1 min with $50 \mu \mathrm{l}$ of chloroform in a Reacti-Vial, whereafter the suspension was centrifuged at $3000 \mathrm{rpm}$ for 10 min. In this solvent the white carrier material was concentrated in the upper layers of the solvent, while remaining dust particles were precipitated. The solvent, containing soluble organic ma- 
terial, was carefully removed from between these two layers of solid material with a $100 \mu \mathrm{l}$ syringe, the process was repeated a number of times and the extracts pooled and concentrated for analysis of the volatile components of the secretion. The process was finally repeated with dichloromethane as solvent, in which the carrier material tended to remain in suspension. This suspension was removed from the heavier dust particles, diluted with $n$-pentane and centrifuged at $3000 \mathrm{rpm}$ for $10 \mathrm{~min}$. The solvent was removed from the precipitated pure white carrier material which was then dried under reduced pressure at room temperature.

\section{Mass spectrometry}

FAB mass spectra were obtained with a Kratos MS 50 RF mass spectrometer equipped with a high field magnet and a Kratos FAB source, using a $6-8 \mathrm{kV}$ xenon beam (source pressure $10^{-5}$ Torr). Thioglycerol, containing a trace of oxalic acid, was used as matrix on a copper tip. The sample was introduced in a small quantity of water. Spectra were recorded at an accelerating voltage of $8 \mathrm{kV}$ at a resolution of 1000. Exact mass determination was performed by peak-matching at a resolution of 10,000. All spectra were accumulated with a Tracor TN 1710 multi-channel analyzer.

Plasma desorption mass spectrometry (PDMS) was performed on a Bio Ion Bin $20 \mathrm{~K}$ plasma desorption mass spectrometer using nitrocellulose as a matrix [4]. The samples were applied from $5-10 \mu \mathrm{l}$ of $0.1 \%$ trifluoroacetic acid (TFA) solutions and micro-washed with $5-10 \mu \mathrm{l}$ of the same solvent [5]. The instrumentation and data handling procedures have been discussed by Sundqvist et al. [6].

\section{Gas chromatography}

Gas chromatographic determinations were carried out with a Carlo Erba 5300 (Mega) gas chromatograph equipped with a FID detector and a $40 \mathrm{~m} \times 0.3 \mathrm{~mm}$ glass capillary column coated with OV-1701-OH at a film thickness of $0.32 \mu \mathrm{m}$. Helium was used as carrier gas at a linear velocity of $28.5 \mathrm{~cm} / \mathrm{s}$ at $40^{\circ} \mathrm{C}$ and a temperature program of $2{ }^{\circ} \mathrm{C} /$ min from $40^{\circ} \mathrm{C}$ to $250^{\circ} \mathrm{C}$ was employed.

\section{Electrophoresis}

Polyacrylamide slabgel electrophoresis in 15\% acrylamide was performed in the presence of so- dium dodecyl sulphate (SDS) [7]. Proteins $(100 \mu \mathrm{g} /$ $100 \mu \mathrm{l})$ were dissolved in the $\beta$-mercaptoethanolcontaining application buffer of which $20 \mu \mathrm{l}$ was applied per lane. Gels were stained with Coomassie Brilliant Blue R 250 and scanned with a Vitatron densitometer.

\section{Electroelution}

The two major bands BL 1 and BL 2, containing the 31 and $15 \mathrm{kDa}$ proteins respectively, were cut from five lanes of a SDS-PAGE of the carrier material from Kheper lamarcki, soaked for $1 \mathrm{~h}$ in $0.5 \%$ cetylpyridinium bromide $/ 0.5 \mathrm{M}$ acetic acid, and the proteins, together with the Coomassie stain, electroeluted into a $200 \mu$ chamber, formed by a porous and a dialysis membrane, at a field strength of $6 \mathrm{~V} / \mathrm{cm}$ for $3 \mathrm{~h}$, using $0.5 \mathrm{~m}$ acetic acid as electrode buffer according to Hunkapiller et al. [8]. The contents of the electroelution chamber was freeze dried, dissolved in $100 \mu \mathrm{l}$ of methanol, followed by $100 \mu \mathrm{l}$ of $\mathrm{H}_{2} \mathrm{O}$, and the protein precipitated by the addition of $1 \mathrm{ml}$ of cold acetone. The precipitated protein was collected by centrifugation, washed in neat acetone and dried in vacuo.

\section{Amino acid analysis}

Quantitative determination of the amino acids present in the proteins was carried out according to Hirs et al. [9].

\section{HPLC purification}

The proteins, collected from different species, were washed with organic solvents as described above, dissolved in $0.1 \%$ TFA at concentrations of $1 \mathrm{mg} / \mathrm{ml}$, and $100 \mu \mathrm{l}$ of the resulting solution loaded on a $30 \times 0.4 \mathrm{~cm}$ column packed with $\mathrm{Vy}$ dac-C4 $(10 \mu)$, equilibrated with $0.1 \%(w / v)$ TFA (solvent $\mathrm{A}$ ) and eluted with a linear gradient of $70 \%$ acetonitrile containing $0.1 \%$ TFA (solvent B) at a flow rate of $1 \mathrm{ml} / \mathrm{min}$ (Fig. 4). On separation both the $K$. lamarcki and $K$. nigroaeneus proteins gave sharply eluting first fractions, FL 1 and FN 1 respectively. The second fractions, FL 2 and FN2 respectively, were detected and collected as broad peaks and clearly consisted of mixtures of a number of minor constituents. These fractions were concentrated in a stream of $\mathrm{N}_{2}$, freeze dried and subsequently dissolved in $100 \mu$ l of water. Of these first and second fractions, samples of respectively 
10 and $20 \mu 1$ were dissolved in equal volumes of SDS sample application buffer and subjected to electrophoresis. Amino acid composition and sequence analyses were carried out with $10 \mu \mathrm{l}$ quantities of the first and second fractions.

\section{Sequencing}

Protein sequencing was performed by automated isothiocyanate degradations on a gas-phase sequencer which was used as described previously [10]. Isothiocyanate degradations were carried out with $10 \mu \mathrm{l}$ quantities of the fractions isolated by HPLC and dissolved in $100 \mu$ of water. The resulting PTH-amino acids were identified by reversed phase HPLC on a LiChrosphere C8 column (Merck), using a methanol gradient as described previously [11]. The proteins isolated from the HPLC fractions FL 1 and FN 1 and electroeluted from the SDS-PAGE band BL2 were all sequenced twice. The second fractions FL2 and FN2 did not yield significant amounts of PTHamino acids.

\section{Pheromone affinity of the carrier material}

For comparison of the pheromone affinity of the carrier material with that of trypsin and albumin, glass-fibre wicks were coated with these proteins, exposed to the vapour of the major active component of the K. lamarcki secretion, and the adsorbed material determined gas chromatographically. The carrier protein used in these experiments was subjected to a gas-phase stripping of any volatiles not removed by solvent extraction of the abdominal secretion.

The electrical wire and inner insulating layers were carefully pulled out of the finely woven outer insulating glass-fibre sheath of the leads of a cartridge heater which had been salvaged from an old gas chromatograph. The glass fibre was cleaned by heating it overnight in an oven at $500^{\circ} \mathrm{C}$, leaching any heavy metal ions from the fibres with $20 \%$ $\mathrm{HCl}$ at room temperature for several hours, rinsing thoroughly with distilled water and finally drying the clean material at $120^{\circ} \mathrm{C}$. The resulting pure white glass-fibre sheath was cut into $50 \mathrm{~mm}$ lengths weighing $60 \mathrm{mg}$ each. A number of these wicks were coated with either bovine albumin, bovine pancreas trypsin or the carrier protein from $K$. lamarcki. This was done by dissolving $1.5 \mathrm{mg}$ of one of the proteins in $200 \mu$ of distilled water or, in the case of the carrier protein, $0.1 \%$ TFA, and allowing the solution to be drawn up into a wick by capillary action, whereafter the wet glass-fibre wick was suspended on a thin glass rod to dry. The process of moistening with the remaining solution and drying was repeated once or twice in order to transfer all of the protein solution to the glass fibre. The coated wicks were finally dried overnight at room temperature.

A five-pronged framework was constructed from $1.0 \mathrm{~mm}$ glass rod as shown in Fig. 1 with the central, slightly longer prong supporting the framework and the other four arranged around the central one at equal distances from each other. The three protein-coated wicks and a fourth uncoated one were slipped onto the four outer prongs. A fifth wick was treated with 2,6-dimethyl-5-heptenoic acid by dissolving $100 \mu \mathrm{g}$ of the acid in $150 \mu \mathrm{l}$ of dichloromethane, allowing this solution to be sucked up by the glass-fibre material and leaving the treated wick to dry at room temperature for $3 \mathrm{~h}$. This pheromone-dispensing wick was slipped onto the central prong and the framework evacuated to 400 Torr in a glass vial $(28 \mathrm{~mm}$ O.D. $\times 140 \mathrm{~mm}$ ) fitted with a tap socket. The eva-

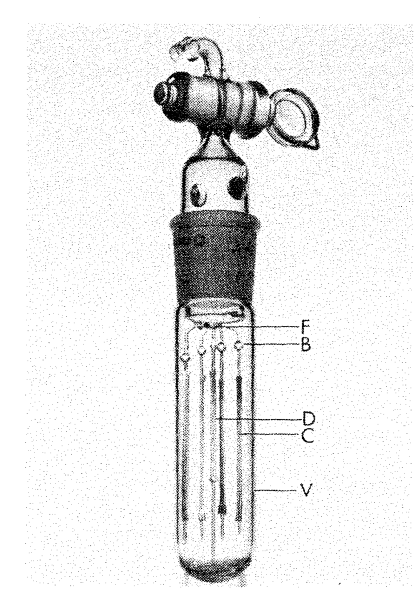

Fig. 1. Device for the determination of the affinity of various proteins for 2,6-dimethyl-5-heptenoic acid. V, Glass vial $(28 \mathrm{~mm}$ O.D. $\times 140 \mathrm{~mm})$ fitted with a tap socket; F, Five-pronged glass framework constructed from $1.0 \mathrm{~mm}$ glass rod and supported on the central prong; B, Glass beads formed in the framework to keep the outer four prongs from touching the wall of the vial; D, Dispensing glass-fibre wick treated with the acid; C, Adsorbing wicks (collectors). 
cuated tube with its contents was kept at $30^{\circ} \mathrm{C}$ for periods varying between one and eight days, whereafter the amount of the unsaturated acid adsorbed on the four collectors, as well as the acid left on the dispensing wick was determined gas chromatographically. This was done by inserting each wick into a wide-bore injector liner and desorbing the adsorbed acid onto the capillary column at an injector temperature of $100^{\circ} \mathrm{C}$ for periods up to $1 \frac{1}{2}$ h. 2,6-Dimethyl-5-heptenoic acid was used as external standard in these determinations.

In order to remove any adsorbed volatiles and to assure that the carrier protein did not contain any residual 2,5-dimethyl-5-heptenoic acid, the coated wicks as well as the uncoated control were subjected to desorption at $100^{\circ} \mathrm{C}$ and quantitative determination of the desorbed material before an experiment was started. Before and after determinations the wicks were stored in evacuated glass tubes.

\section{Results and Discussion}

All three Kheper species currently under investigation, produce the carrier, K. lamarcki and $K$. subaeneus in the form of a relatively broad ribbon of fibres, about $4 \mathrm{~mm}$ in width, whereas $K$. nigroaeneus produces a much narrower band or thread of fibres. As far as the diameter of the fibres and their brittleness are concerned, the three species produce similar material, although that of $K$. subaeneus appears to be softer and slightly sticky. Initial experiments carried out under a microscope with very little material from $K$. lamarcki, seemed to indicate that it dissolves only in concentrated sulphuric acid. However, as more material from this and the other two species became available, it transpired that it is also soluble in other polar and especially acidic solvents, such as trifluoroacetic acid. It was therefore possible to compare the carrier material produced by the three Kheper species by analytical procedures employed in protein analysis.

SDS-polyacrylamide gel-electrophoresis (SDSPAGE) of the proteinaceous components of the abdominal secretions of the three Kheper species (Fig. 2) reveals the presence in each secretion of components possessing molecular masses of $\mathrm{ca}$. $17 \mathrm{kDa}$ and $c a .31 \mathrm{kDa}$ respectively and together comprising about $90 \%$ of the stained proteins present. The additional minor components present

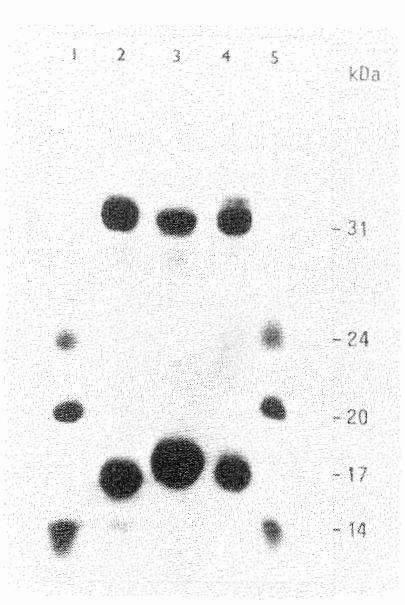

Fig. 2. SDS-PAGE of the pheromone disseminating carrier from Kheper lamarcki (lane 2), K. nigroaeneus (lane 3), K. subaeneus (lane 4) and mass marker proteins (lanes 1 and 5): trypsinogen, $24 \mathrm{kDa}$; soybean trypsin inhibitor, $20.1 \mathrm{kDa}, \alpha$-lactalbumin, $14.2 \mathrm{kDa}$. The gel was loaded with $20 \mu \mathrm{g}$ per lane of the crude secretion from which soluble organic material had been extracted with chloroform, dichlormethane and $n$-pentane. The gel was stained with Coomassie Brilliant Blue R 250. Molecular masses are given in kilodalton $(\mathrm{kDa})$.

seem to be largely high molecular mass proteins. The predominant fraction is a $17 \mathrm{kDa}$ protein. In the absence of the reducing agent $\beta$-mercaptoethanol, the apparent molecular mass of the $17 \mathrm{kDa}$ protein decreases to $15 \mathrm{kDa}$ (Fig. 3). This

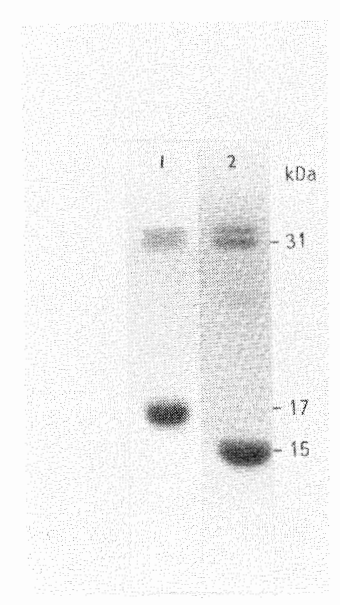

Fig. 3. SDS-PAGE of the pheromone disseminating carrier from Kheper nigroaeneus, applied in buffer containing $\beta$-mercaptoethanol (lane 1), and in the absence of the reducing agent (lane 2). Molecular masses are given in kilodalton $(\mathrm{kDa})$. 
seems to indicate that the naturally occurring protein exists as a compactly folded protein, stabilized by intramolecular disulphide linkages. On breaking these linkages with $\beta$-mercaptoethanol, the molecule unfolds to a more extended molecule with a lower mobility. Minor differences in the electrophoretic mobility of this protein in the material secreted by the three species are apparent from Fig. 2 and may reflect minor differences in its overall structure.

In addition to the fact that $K$. subaeneus secretes very little abdominal secretion, only three males of this species could be found during the 1988-89 season. Further analytical work was therefore carried out with the other two species only.

Quantitative determination of the peak area profiles of the SDS-PAGE of the secretion from these two species showed that the $31 \mathrm{kDa}$ band consists of several proteins in $K$. nigroaeneus and at least two in $K$. lamarcki. Using HPLC, two fractions were isolated from each secretion as shown in Fig. 4, fractions FL1 and FN1 containing the $15 \mathrm{kDa}$ protein and fractions FL 2 and FN2 the various $31 \mathrm{kDa}$ proteins. The results of amino acid analyses carried out on the F 1 and F 2 fractions of both secretions (Table I), confirm the overall similarity of the two fractions of each secretion as well as the similarity of the secretions from the two species, but on the other hand, also reveal marked differences between the two fractions of a specific carrier material, as well as between, for example, fractions FL 1 and FN 1. The possibility that the $31 \mathrm{kDa}$ proteins might be differently linked dimers of the smaller protein was taken into consideration and it is possible that at least one of these proteins in each of the secretions could be a dimer. Further work on the $31 \mathrm{kDa}$ fractions is necessary to establish the nature of such possible dimers and of the other proteins present in these fractions.

In the present investigation further work was concentrated on the $15 \mathrm{kDa}$ proteins of the two carrier materials. Complete amino acid sequencing was not attempted, but partial sequence analyses (10 cycles), the results of which are given in Table II, were repeated several times and revealed a single sequence to be present in the $15 \mathrm{kDa}$ protein isolated from $K$. nigroaeneus carrier material.

In contrast, two sequences appeared to be pres-
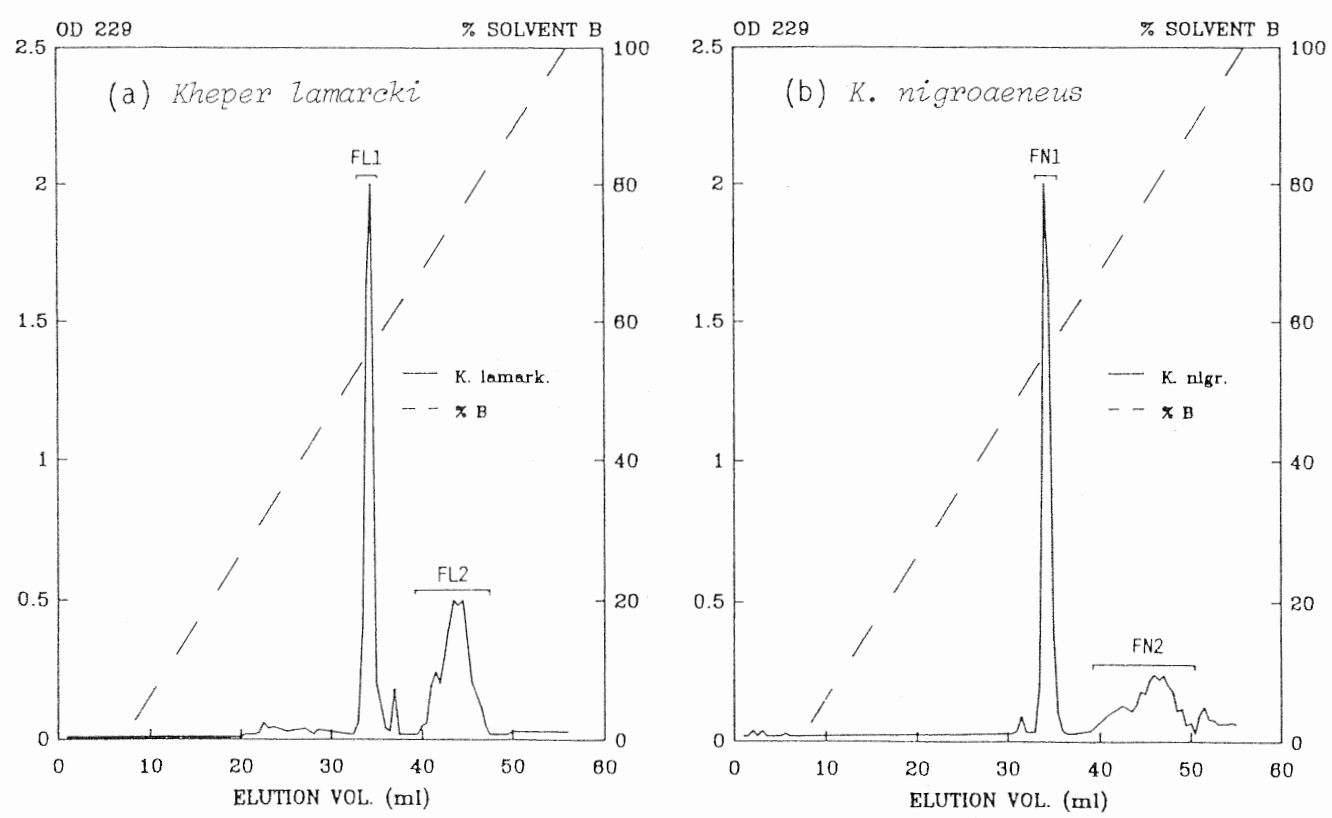

Fig. 4. Separation of the proteins present in the pheromone disseminating secretion of Kheper lamarcki (a) and $K$. nigroaeneus (b). A reversed phase column $\left(\mathrm{C}_{4}, 10 \mu, \mathrm{Vydac}\right)$ was loaded with $100 \mu \mathrm{g}$ quantities of the secretion dissolved in $100 \mu 1$ of $0.05 \%$ trifluoroacetic acid (TFA) and eluted with an acetonitrile gradient. Buffer A: $0.1 \%$ TFA in water; buffer B: $70 \%$ acetonitrile containing $0.1 \%$ TFA. Fractions were collected as shown in the figures. 
Table 1. Comparison of the amino acid composition of the $15 \mathrm{kDa}$ fractions FL 1 and FN 1 , the $31 \mathrm{kDa}$ fractions FL 2 and FN 2, isolated by HPLC (Fig. 4) from the pheromone disseminating carrier of Kheper lamarcki and $K$. nigroaeneus, and the $15 \mathrm{kDa}$ band (BL 1 ) electroeluted from a SDS-PAGE gel of $K$. lamarcki carrier material.

\begin{tabular}{|c|c|c|c|c|c|}
\hline \multirow[t]{2}{*}{$\begin{array}{l}\text { Amino } \\
\text { acid }\end{array}$} & \multicolumn{3}{|c|}{$\begin{array}{l}\text { Mole percent } \\
K . \text { lamarcki }\end{array}$} & \multicolumn{2}{|c|}{ K.nigroaeneus } \\
\hline & FL 1 & FL.2 & BL 2 & FN 1 & FN2 \\
\hline Asp & 11.1 & 12.5 & 12.8 & 12.5 & 12.8 \\
\hline Thr & 5.2 & 5.4 & 5.4 & 7.1 & 5.7 \\
\hline Ser & 5.7 & 4.4 & 6.0 & 7.7 & 5.0 \\
\hline Glu & 9.9 & 10.1 & 6.5 & 7.9 & 9.2 \\
\hline Pro & 7.8 & 4.7 & 7.6 & 7.5 & 5.0 \\
\hline Gly & 7.4 & 8.1 & 8.6 & 7.5 & 9.2 \\
\hline Ala & 10.1 & 6.1 & 5.7 & 6.5 & 6.4 \\
\hline Cys & 2.8 & 2.4 & 1.3 & 4.0 & 2.1 \\
\hline Val & 9.0 & 6.4 & 9.6 & 8.5 & 6.4 \\
\hline Met & 0.7 & 1.7 & 1.3 & 0.2 & 1.4 \\
\hline Ile & 4.9 & 6.8 & 4.7 & 4.1 & 6.4 \\
\hline Leu & 8.7 & 9.5 & 9.0 & 9.1 & 8.5 \\
\hline Tyr & 2.2 & 3.7 & 2.9 & 2.7 & 4.3 \\
\hline Phe & 2.8 & 4.1 & 2.9 & 0.8 & 4.3 \\
\hline Trp & 0.8 & 0.7 & 1.0 & 0.8 & 0.7 \\
\hline His & 1.8 & 1.0 & 2.2 & 2.7 & 2.1 \\
\hline Lys & 7.6 & 8.4 & 10.6 & 7.4 & 8.5 \\
\hline Arg & 1.5 & 4.1 & 1.9 & 2.8 & 2.1 \\
\hline Total & 100.0 & 100.0 & 100.0 & 100.0 & 100.0 \\
\hline
\end{tabular}

ent in the major constituent from $K$. lamarcki carrier material. One possible explanation of this result is that a labile peptide bond is broken close to the C-terminal end, possibly during the isolation procedure, giving rise to two fragments having different sequences. The fact that the protein when electroeluted from the SDS gel, showed only a single sequence (Table II) apparently confirms this assumption and it is therefore accepted that the two major constituents of the pheromone disseminating secretions of these two species have the following unique partial sequences with Xxx denoting modified or unusual amino acids:

K. lamarcki:

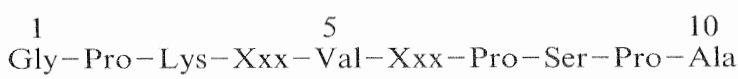

K. nigroaeneus:

Gly-Pro-Lys-Xxx-Ala-Xxx-Pro-Thr-Pro-Ala

In the previous paper on the sex attracting secretion of male Kheper lamarcki, unsuccessful attempts to obtain a FAB mass spectrum of the carrier polypeptide were reported [1]. In the present study the molecular mass of the $15 \mathrm{kDa}$ protein of the pheromone disseminating carrier material of the two species was verified by ${ }^{252} \mathrm{Cf}$ plasma de-

Table II. Amino acids recovered during the phenylisothiocyanate degradation of the $15 \mathrm{kDa}$ fractions FL 1 and FN 1, isolated by HPLC (Fig. 4) from the pheromone disseminating carrier of Kheper lamarcki and K. nigroaeneus, and the $15 \mathrm{kDa}$ band BL 2 electroeluted from a SDS-PAGE of $K$. lamarcki carrier material. Xxx denotes undetected, atypical or modified amino acids.

\begin{tabular}{|c|c|c|c|c|c|c|c|c|}
\hline \multirow{3}{*}{ Cycle } & \multicolumn{4}{|c|}{$\begin{array}{l}\text { K. lamarcki } \\
\text { FL } 1\end{array}$} & \multicolumn{2}{|l|}{ BI 2} & \multicolumn{2}{|c|}{ K. Nigroaeneus } \\
\hline & $\begin{array}{l}\text { FLI } \\
\text { PTH }\end{array}$ & & Yield & & $\begin{array}{l}\text { BL } 2 \\
\text { PTH }\end{array}$ & Yield & $\begin{array}{l}\text { FN1 } \\
\text { PTH }\end{array}$ & Yield \\
\hline & a.a. & & & & a.a. & & a.a. & \\
\hline 1 & Gly & Phe & 548 & 756 & Gly & 145 & Gly & 640 \\
\hline 2 & Pro & Ala & 319 & 874 & Pro & 71 & Pro & 221 \\
\hline 3 & Lys & Val & 252 & 860 & Lys & 29 & Lys & 181 \\
\hline 4 & $\mathrm{Xxx}$ & Glu & 0 & 665 & $\mathrm{Xxx}$ & 0 & $X x x$ & 0 \\
\hline 5 & Val & Glu & 534 & 770 & Val & 75 & Ala & 402 \\
\hline 6 & $\mathrm{Xxx}$ & Glu & 0 & 552 & $\mathrm{Xxx}$ & 0 & $\mathrm{Xxx}$ & 0 \\
\hline 7 & Pro & Leu & 387 & 549 & Pro & 51 & Pro & 314 \\
\hline 8 & Ser & Pro & 188 & 525 & Ser & 14 & Thr & 137 \\
\hline 9 & Pro & $\mathrm{Xxx}$ & 462 & 0 & Pro & 45 & Pro & 343 \\
\hline 10 & Ala & Gin & 362 & 388 & Ala & 41 & Ala & 267 \\
\hline \multicolumn{3}{|c|}{ Repetitive yield } & 95.5 & 94.8 & & 86.9 & & 90.7 \\
\hline
\end{tabular}


sorption mass spectrometry. Nitrocellulose was used as adsorbing backing [4]. From the abundant $\mathrm{MH}_{4}^{4+}, \mathrm{MH}_{3}^{3+}$ and $\mathrm{MH}_{2}^{2+}$ ions at respectively $\mathrm{m} / \mathrm{z}$ $3862.0,5150.7$ and 7731.5 in the spectrum of the $K$. lamarcki material (Fig. 5 a) an average molecular mass of $15451 \pm 10$ Da was calculated for the protein that gave rise to these ions. The ion at $\mathrm{m} / \mathrm{z}$ 3477.0 in this spectrum probably indicates the presence of an impurity with molecular mass 3476 $\mathrm{Da}$, if it is assumed that only the monoprotonated ion is observed in this case. It is possible that it is this impurity which gave the second amino acid sequence for the $15 \mathrm{kDa}$ fraction isolated by HPLC from the $K$. lamarcki secretion. In the spectrum of the material from $K$. nigroaeneus (Fig. 5 b) the four ions at $m / z 3099.0,3867.4,5159.5$ and 7740.1 can be assigned to $\mathrm{MH}_{5}^{5+}, \mathrm{MH}_{4}^{4+}, \mathrm{MH}_{3}^{3+}$ and $\mathrm{MH}_{2}^{2+}$ ions respectively, giving a molecular mass of $15477 \pm 10 \mathrm{Da}$ for the protein in question.

Due to the presence of relatively large amounts of glutamic and aspartic acid and smaller amounts of the basic amino acids, the proteinaceous carrier materials are expected to have low isoelectric points. The proteins also contain large amounts of hydrophobic amino acids. As most of the volatile compounds present in the abdominal secretion of these insects, and especially the major constituents showing electroantennogram activity are long-
B. V. Burger et al. - Pheromones of the Scarabaeinae, II

chain fatty acids, these properties were not totally unexpected.

The amino acid composition of this protein (Table I) is similar in certain respects to that of serum albumin [12] which is known to bind a large number of hydrophobic compounds, including dodecyl sulphate and fatty acids [13]. This suggests that this protein might have a high affinity for compounds such as the fatty acid 2,6-dimethyl5 -heptenoic acid, the major one of only a few constituents of the $K$. lamarcki secretion which exhibit electroantennogram activity [14], and might therefore be involved in the transport and controlled release of the volatile dung beetle pheromones. Since the protein has a large surface area in the form in which it is secreted, it may, on the other hand, also serve to accelerate evaporation of the adsorbed volatile constituents. A number of experiments were carried out in an attempt to compare the affinity of the carrier protein for this unsaturated acid with that of proteins such as albumin and trypsin. Albumin, trypsin and the carrier protein were, for example, exposed to the volatiles emitted by a fresh sample of the abdominal secretion. In these experiments trypsin consistently showed a much lower affinity for the volatiles than albumin or the carrier protein.

It could, however, not be ruled out that these re-
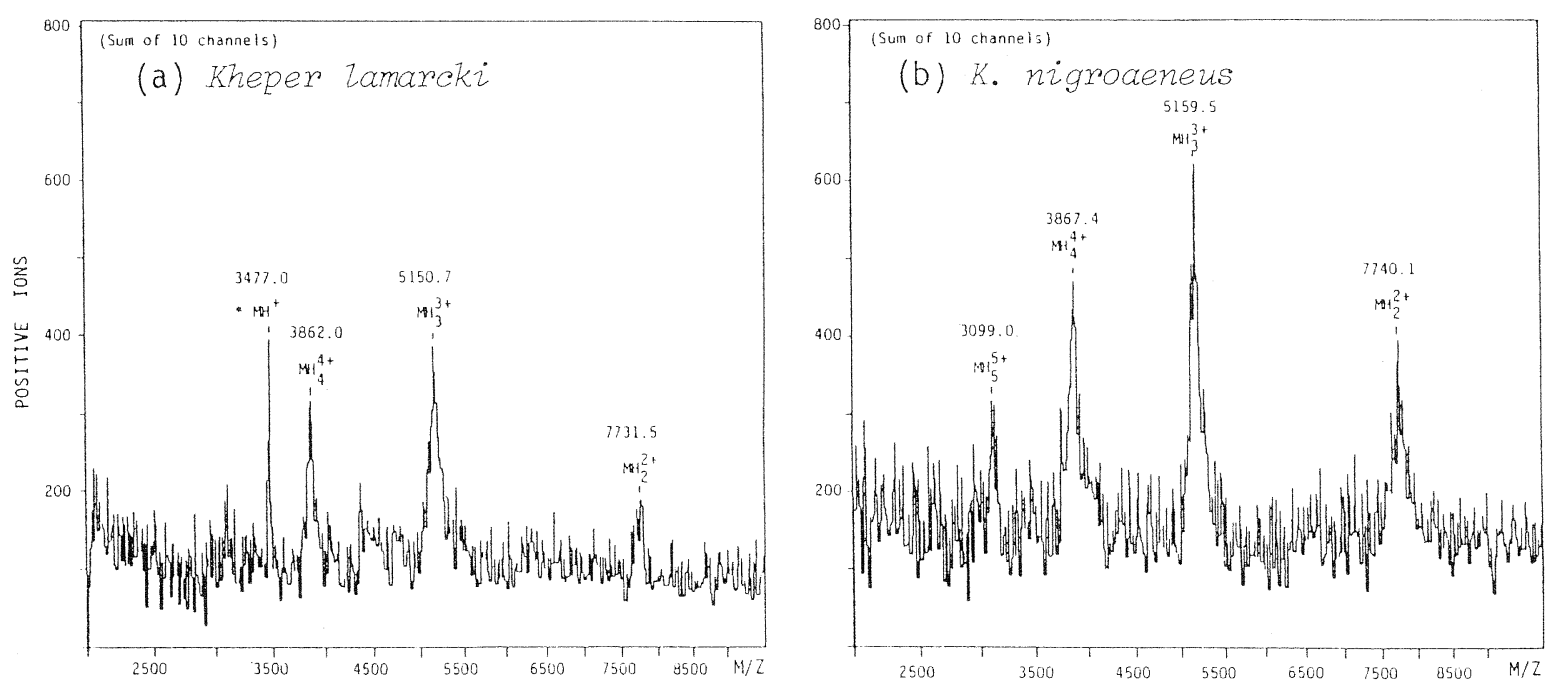

Fig. 5. Plasma desorption mass spectra of $15 \mathrm{kDa}$ proteins from $K$. lamarcki (a) and $K$. nigroaeneus (b). The proteins were isolated from the pheromone disseminating carrier by HPLC and were applied to nitrocellulose matrices from $0.1 \%$ trifluroacetic acid solutions. 
sults were produced by differences in the surface area of the proteins rather than differences in their chemical properties. An experiment was therefore devised in which glass-fibre wicks coated with the proteins, as well as an untreated wick, were exposed to the vapour of 2,6-dimethyl-5-heptenoic acid. This experiment was carried out at a temperature at which these dung beetles typically produce the abdominal secretion and at a slightly reduced pressure to promote molecular mobility.

A series of determinations using exposure times of one, four and eight days were carried out. In all of these experiments trypsin retained only about a third of the amount of acid that was recovered from the carrier protein or albumin, the albumin/ trypsin ratio varying between 2.9 and 3.1 and the carrier/trypsin ratio between 3.0 and 3.7. In line with these results, it was found that at an injector temperature of $100^{\circ} \mathrm{C}$ the desorption of the acid proceeded at a much faster rate from trypsin than from the other two proteins which required $1 \frac{1}{2} \mathrm{~h}$ for quantitative desorption of the acid.

Although the object of coating inert support material with solutions of the proteins was to eliminate differences in the physical state of the proteins as far as possible, the glass fibre also has a high affinity for polar compounds, due to the presence of silanol groups on the glass surface. This is confirmed by the set of typical results given in Table III, according to which the glass fibre has a higher affinity for the acid than the trypsin-coated material. Using an apolar support material or elimination of the silanol groups by persilylation to produce a totally apolar surface, would seem to be a logical solution to this problem. However, polar compounds or solutions containing polar sub- stances form droplets on apolar surfaces and cannot therefore the coated uniformly on such surfaces. In this regard it must, however, be taken into consideration that active sites on the glass surfaces will be blocked very effectively by the large variety of polar groups present in proteins and that different proteins can be expected to block and deactivate such active sites on similarly prepared glass surfaces approximately equally effectively. The glass fibre therefore acts as an inert support once it is coated with a protein. Strictly speaking the coated wick therefore does not serve as a control. It is nevertheless interesting to compare the affinity of the leached glass fibre with that of the proteins.

The results given in Table III show that albumin and the carrier protein adsorb the acid approximately equally effectively, with trypsin retaining the acid about three times less effectively. This lends further support to the conclusion that albumin should be a suitable substitute for the carrier protein in field tests. The strong retention of the acid by the carrier protein suggests that controlled release in order to retain the integrity of a complex message as long as possible, rather than rapid release of the pheromone, might be the primary function of the carrier protein. It is possible that this interesting and unique pheromone disseminating mechanism is more effective under adverse climatic conditions than other release mechanisms normally employed by insects.

\section{Acknowledgements}

Support by the Universities of Stellenbosch and Cape Town and the Foundation for Research De-

Table III. Quantitative determination of the 2,6-dimethyl-5-heptenoic acid recovered from a dispensing glass-fibre wick treated with a solution of $100 \mu \mathrm{g}$ of the acid in $150 \mu$ of $\mathrm{CH}_{2} \mathrm{Cl}_{2}$ and from four adsorbing wicks which had been exposed to the vapour of this acid for eight days at $30^{\circ} \mathrm{C}$. Three of these wicks were coated with respectively trypsin, albumin and $K$. lamarcki carrier protein while the fourth was left uncoated.

\begin{tabular}{|c|c|c|c|c|c|}
\hline Wick & Dispenser & Control & Trypsin & Albumin & Carrier \\
\hline Acid recovered $(\mu \mathrm{g})^{*}$ & 4.02 & 1.73 & 0.83 & 2.48 & 2.55 \\
\hline
\end{tabular}

* The acid not accounted for, was lost during removal of the solvent $\left(\mathrm{CH}_{2} \mathrm{Cl}_{2}\right)$ from the dispensing wick and evacuation of the vial in which the experiment was carried out, as well as by adsorption on the glass surface of the vial. 
velopment, Pretoria, is gratefully acknowledged. The authors are indebted to the Natal Parks, Game and Fish Preservation Board for permission to study and collect dung beetles in the Mkuzi and

[1] B. V. Burger, Z. Munro, M. Röth, H. S. C. Spies, V. Truter, G. D. Tribe, and R. M. Crewe, Z. Naturforsch.38c, 848 (1983).

[2] W. Blum, HRC \& CC 8, 718 (1985).

[3] G. D. Tribe, M. Sc. Thesis, pp. 35-36, University of Natal, Pietermaritzburg, South Africa, 1976.

[4] G. P. Jonsson, A. B. Hedin, P. L. Håkansson, B. U. R. Sundqvist, B. G. S. Säve, P. Nielsen, P. Roepstorff, K. E. Johansson, I. Kamensky, and M. S. L. Lindberg, Anal. Chem. 58, 1084 (1986).

[5] P. F. Nielsen, K. Klarskov, P. Højrup, and P. Roepstorff, Biomed. and Environ. Mass Spectrom. 17, 355 (1988)

[6] B. Sundqvist, I. Kamensky, P. Håkansson, J. Kjellberg, M. Salehpour, S. Widdiyasekera, J. Fohlman, P. A. Peterson, and P. Roepstorff, Biomed. Mass Spectrom. 11,242 (1984).
Hluhluwe Game Reserves and to Prof. Peter Roepstorff for invaluable advice and assistance in connection with the plasma desorption mass spectral measurements.

[7] U. K. Laemmli, Nature (London) 227, 680 (1970).

[8] M. W. Hunkapiller, E. Lujan, F. Ostrander, and L. E. Hood, Methods Enzymol. 91, 227-236 (1983).

[9] C. H. W. Hirs, Methods Enzymol. 11, 197-199 (1967).

[10] W. F. Brandt, H. Alk, M. Chauhan, and C. von Holt, FEBS Lett. 174, 228 (1984).

[11] M. S. Strickland, W. N. Strickland, W. F. Brandt, C. von Holt, B. Wittmann-Liebold, and A. Lehmann, Eur. J. Biochem. 89, 443 (1978).

[12] T. Peters and C. Hawn, J. Biol. Chem. 242, 1566 (1967).

[13] F. W. Putnam, The Proteins III (H. Neurath, ed.), pp. 153-267, Academic Press, New York 1965.

[14] B. V. Burger, Z. M. Munro, and W. G. B. Petersen, unpublished results. 